\title{
Case Report and Review of the Literature
}

\section{Cryptococcal Endocarditis in a Woman with Metastatic Non-Small Cell Lung Cancer: A Case Report and Review of the Literature}

\author{
Tony Kurian $^{1^{*}}$, Jason Peng ${ }^{2}$, Courtney Regan Wagner ${ }^{3}$ and Fritzie Albarillo $^{4}$ \\ ${ }^{1}$ Moffitt Cancer Center/USF, Tampa, Florida, USA \\ ${ }^{2}$ Department of Internal Medicine, Loyola University Medical Center, Maywood, Illinois, USA \\ ${ }^{3}$ Division of Infectious Diseases, Loyola University Medical Center, Maywood, Illinois, USA \\ ${ }^{4}$ Division of Hematology Oncology, Loyola University Medical Center, Maywood, Illinois, USA
}

\begin{tabular}{l} 
A R T I C L E I N F O \\
\hline Article history: \\
Received: 8 July, 2020 \\
Accepted: 21 July, 2020 \\
Published: 27 July, 2020 \\
\hline Keywords: \\
Cryptococcal endocarditis \\
cryptococcal meningitis \\
non-small cell lung cancer \\
tyrosine kinase inhibitor \\
erlotinib \\
targeted therapy
\end{tabular}

\begin{abstract}
A B S T R A C T
Epidermal growth factor receptor tyrosine kinase inhibitors (EGFR-TKIs) have demonstrated improved progression-free survival benefits and decreased treatment-related side effects, and therefore are now considered first-line of treatment of EGFR mutated, metastatic non-small cell lung carcinoma (NSCLC). Cryptococcal endocarditis is an extremely rare clinical entity with only seven reported cases in the literature. Prior cases were seen in patients with a history of rheumatic heart disease or prior valve replacement surgery. Little is known regarding the natural history and optimal management of Cryptococcal endocarditis, given the limited available data. We present a case of Cryptococcal endocarditis and meningitis in a patient with metastatic NSCLC receiving targeted therapy with an EGFR-TKI with no history of significant cardiac disease.
\end{abstract}

\section{Introduction}

Epidermal growth factor receptors (EGFR) are cell surface transmembrane receptors belonging to the epidermal growth factor (EGF) family of extracellular protein ligands and includes the ErbB1 and HER 1 families. The ErbB receptor family consists of 4 receptor tyrosine kinases: EGFR, HER2, HER3, HER4. EGF binds EGFR activating multiple pathways in cell proliferation, survival, metastasis, and neoangiogenesis $[1,2]$. EGFR mutations occur in 10-26\% of NSCLCs and include in-frame deletions in exon 19 and amino acid substitution at codon 858 [2]. Several landmark studies over the past decade have demonstrated progression-free survival (PFS) benefit and decreased treatment-related severe side effects and death of EGFR TKIs when compared to standard chemotherapy for patients with metastatic NSCLC with sensitizing EGFR mutations [3-8]. EGFR-TKIs including erlotinib, gefitinib, afatinib, dacomitinib and osimertinib are now recommended as first-line systemic therapy in patients with sensitizing EGFR mutation in the latest National Comprehensive Cancer Network (NCCN) guidelines for management of NSCLC [9].

The Iressa Pan-Asia Study (IPASS) in 2009 first demonstrated the efficacy of EGFR-TKIs by comparing gefitinib to systemic chemotherapy [5]. The European Tarceva versus Chemotherapy (EURTAC) study later demonstrated the efficacy of erlotinib compared to platinum-based systemic chemotherapy with a response rate of $58 \%$ compared to $15 \%$ and progression-free survival of 10 months compared to 5 months [3]. The study included patients with stage IIIB or IV NSCLC and EGFR mutation who received no prior chemotherapy for metastatic disease. Grade 3 or 4 adverse events were lower in the erlotinib group than systemic chemotherapy ( $45 \%$ vs. $67 \%$, respectively) [3]. The United States Food and Drug Administration (FDA) approval summary for erlotinib notes the rate of infection as $24 \%$ for erlotinib vs $15 \%$ for placebo [10]. However, a meta-analysis on toxicities of erlotinib in treatment of metastatic NSCLC did not comment on the increased risk of infection [11]. Therefore, further investigation is needed regarding

${ }^{*}$ Correspondence to: Tony Kurian, M.D., Moffitt Cancer Center/USF, 12902 USF Magnolia Dr. MCC-GME, Tampa, 33612, Florida, USA; Tel: 8137452069; Fax: 8137454064; E-mail: Tony.Kurian@moffitt.org 
possible increased risk of infectious diseases with targeted therapy agents. In this paper, we will discuss the first known case of a patient with native aortic valve endocarditis secondary to Cryptococcus neoformans in the context of active malignancy undergoing treatment with targeted therapy.

Infective endocarditis is a known cause of cerebrovascular accidents (CVA) occurring in about $35 \%$ of cases [12]. Of these, culture-negative endocarditis accounts for $35 \%$ of cases $[13,14]$. Cryptococcus represents an extremely rare pathogen in endocarditis with only seven reported cases [15-21]. Little is known regarding the natural history and optimal management given the limited available data.

\section{Case Presentation}

The patient is a 60-year-old woman with a history of deep vein thrombosis managed with rivaroxaban who initially presented with back pain in 2015. Imaging revealed changes concerning spinal malignancy with T12 fracture and spinal canal compromise. She then underwent urgent surgical intervention with T10-L2 posterior spinal fusion, laminectomy, decompression, and biopsy of L2 spine lesion. Pathology was consistent with metastatic adenocarcinoma suspicious for a lung primary with immunohistochemical staining pattern revealing positive TTK-1 and CK-7 and negative for CK20, PAX 9, GATA3, ER, PR, and HER2. Molecular studies revealed EGFR L858 mutation. Staging computed tomography (CT) imaging demonstrated a $2.6 \mathrm{~cm}$ right upper lobe nodule without lymphadenopathy but with small pleural effusions, a destructive lesion in the left sacrum, a soft tissue density in the right pelvis, a $2-3 \mathrm{~mm}$ enhancement in the left frontal gyrus, an $11 \mathrm{~mm}$ enhancing lesion in the parietal calvarium, a dura infiltration, and a right foramen magnum nodular enhancement. Positron emission tomography (PET) imaging showed markedly hypermetabolic right upper lobe lesion (SUV 7.2), findings suspicious for metastatic lymphadenopathy in mediastinum and right hilum, and extensive skeletal metastases.

At the time of her initial presentation, her Eastern Cooperative Oncology Group (ECOG) performance status was 3. She was started on erlotinib and received palliative radiation therapy with $30 \mathrm{~Gy}$ in 10 fractions to the thoracolumbar spine and 37.5 Gy in 15 fractions to her left hemipelvis in November 2015. Within a week of starting erlotinib, she was admitted for severe pain and found to have hemoptysis and disseminated intravascular coagulation (DIC). This was thought to be related to a possible tumor lysis-like episode from dramatic tumor cell death. She clinically responded well to erlotinib. Denosumab, a monoclonal antibody was subsequently added during therapy for adjunct management of bone metastases in August 2016. Three and 6-month surveillance imaging revealed no progression of disease, and ECOG performance status improved from 3 to 1 over the course of the first 8 months of treatment.

After 18 months of favorable response to treatment with significant improvement in quality of life and no evident progression of disease, she presented to the emergency room with right-sided weakness and facial droop in April 2017. Magnetic resonance imaging (MRI) of the brain revealed embolic infarcts mostly to the left hemisphere (Figure 1). Transthoracic echocardiogram demonstrated new aortic insufficiency. A subsequent transesophageal echocardiogram demonstrated a round echogenic mass on the left-ventricular side of the non-coronary cusp of the aortic valve measuring $5.1 \times 6.7 \mathrm{~mm}$ and a smaller mass on the right coronary cusp measuring $3.3 \times 3.6 \mathrm{~mm}$ (Figure 2). During this admission, the patient was hemodynamically stable, afebrile, and had no leukocytosis. Blood cultures were negative for bacterial growth. Culturenegative endocarditis work up was subsequently initiated, including urine Histoplasma antigen, urine Blastomyces antigen, urine legionella antigen, Brucella antibodies, Coxiella antibodies, Bartonella antibodies, and Tropheryma whipplei molecular testing. Due to the suspicious morphology of lung nodules, serum Cryptococcal antigen was also obtained.

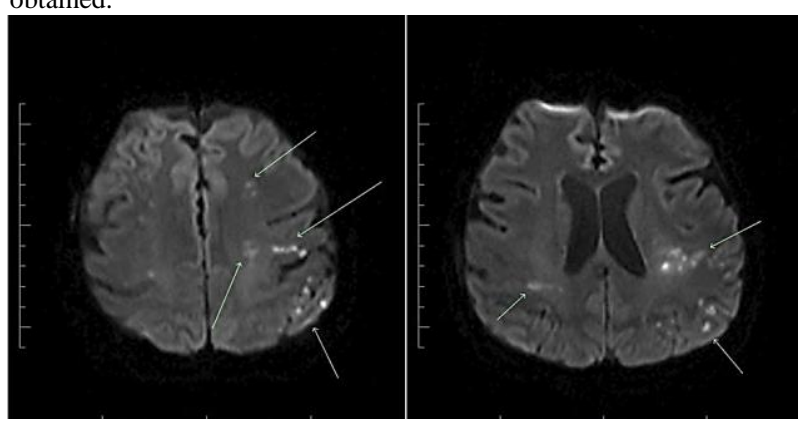

Figure 1: MRI of the brain showing multiple infarcts.

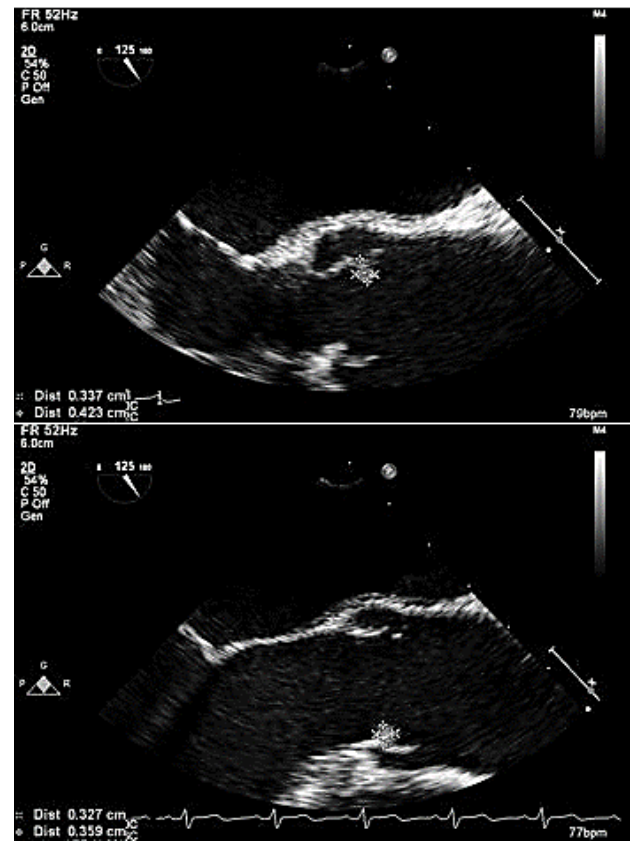

Figure 2: Transesophageal echocardiogram showing 2 masses on the aortic valve.

This later came back positive with a titer of 1:1280. Lumbar puncture (LP) was performed, revealing an elevated opening pressure of $33 \mathrm{~cm}$ with cerebrospinal fluid (CSF) analysis showing 49\% polymorphonuclear neutrophils, $26 \%$ lymphocytes, glucose of 37 $\mathrm{mg} / \mathrm{dL}$, and protein of $32 \mathrm{mg} / \mathrm{dL}$. CSF Cryptococcal antigen titer was elevated at $>=1: 2560$. Treatment was initiated with amphotericin B lipid complex and flucytosine. Fungal blood and CSF cultures later grew Cryptococcus neoformans, confirming the diagnosis. Repeat LP one week later demonstrated decreased Cryptococcal antigen titer of 1:320 and repeat serum Cryptococcal antigen titer decreased to 1:80. Flucytosine was discontinued due to pancytopenia. The patient was to 
complete 6 weeks of amphotericin B and to be transitioned to fluconazole for consolidation therapy. However, her clinical status declined. The risks were deemed to outweigh benefits of further lumbar puncture or valve replacement, and the patient and her family decided to transition to hospice care.

\section{Discussion}

This patient initially presented with advanced, widely metastatic NSCLC with significant disease burden including spinal cord compression and compression fracture requiring neurosurgical intervention, diffuse osseous disease, brain metastasis, thrombosis, tumor induced DIC, and poor performance status. Despite the severity of her disease burden and poor performance status, the patient did remarkably well on treatment with erlotinib, denosumab, and palliative radiation therapy. Over the first year and a half of treatment, her performance status improved and there was no evidence of disease progression on surveillance imaging with the majority of this time spent in the ambulatory setting.

The initial clinical course illustrates the efficacy of EGFR-TKIs in the appropriate patient population. The most recent iteration of the NCCN guidelines recommend that EGFR TKIs should be used as first-line systemic therapy in stage IV lung cancer patients with sensitizing EGFR mutations due to improved PFS when compared to standard chemotherapy. FDA has approved first-line EGFR-TKIs which include erlotinib, gefitinib, afatinib, dacomitinib and osimertinib. These therapies are well tolerated with fewer treatment-related severe side effects and deaths when compared to standard chemotherapy [3, 9]. Poor performance status may not preclude systemic treatment with EGFR TKIs and the guidelines recommend treatment for patients of any performance status, though the decision to treat still remains in the hands of a clinician [9].

The Infectious Diseases Society of America (IDSA) has published guidelines in the management of Cryptococcal diseases [22]. The guidelines recommend that for patients with Cryptococcal meningoencephalitis in non-HIV and nontransplant hosts, amphotericin B deoxycholate plus flucytosine should be utilized for induction therapy for at least 4 weeks, followed by consolidation treatment with fluconazole for 8 weeks [22]. However, there are no clear guidelines in the management of Cryptococcal endocarditis. This case represents the first reported case of Cryptococcal endocarditis in a patient with active malignancy receiving targeted therapy. There have only been seven previously reported cases of Cryptococcal endocarditis in the literature. These cases are summarized in (Table 1) [15-21]. The earliest case was reported in 1957 and the most recent was published in 2011. All previously reported cases were seen in men between the ages of 12-55. Our case, therefore, represents the first case of Cryptococcal endocarditis seen in a woman as well as the oldest known patient with this clinical presentation. In six of the seven cases, patients had a history of rheumatic heart disease or a prosthetic valve.

Table 1: Characteristics of previously reported Cryptococcal endocarditis.

\begin{tabular}{|c|c|c|c|c|c|c|c|c|}
\hline Author & Year & Patient & Risk factors & $\begin{array}{l}\text { Affected } \\
\text { valve }\end{array}$ & $\begin{array}{l}\text { Associated } \\
\text { disease }\end{array}$ & Treatment & $\begin{array}{l}\text { Valvular } \\
\text { surgery }\end{array}$ & Outcome \\
\hline $\begin{array}{l}\text { Lombardo } \\
\text { et al }\end{array}$ & 1957 & $\begin{array}{l}44 \\
\text { year } \\
\text { old } \\
\text { male }\end{array}$ & $\begin{array}{l}\text { Coal miner, } \\
\text { rheumatic heart } \\
\text { disease }\end{array}$ & $\begin{array}{l}\text { Mitral } \\
\text { and } \\
\text { aortic } \\
\text { valve }\end{array}$ & $\begin{array}{l}\text { Meningitis } \\
\text { Fungemia } \\
\text { UTI }\end{array}$ & $\begin{array}{l}\text { Actidione } \\
\text { and } \\
\text { sulfadiazine }\end{array}$ & None & Died \\
\hline $\begin{array}{l}\text { Colmers et } \\
\text { al }\end{array}$ & 1967 & $\begin{array}{l}55 \\
\text { year } \\
\text { old } \\
\text { male }\end{array}$ & $\begin{array}{l}\text { Atrial fibrillation, } \\
\text { rheumatic heart } \\
\text { disease }\end{array}$ & $\begin{array}{l}\text { Mitral } \\
\text { valve }\end{array}$ & Fungemia & $\begin{array}{l}\text { Ampho } B \times x \\
35 \text { days }\end{array}$ & None & Alive \\
\hline $\begin{array}{l}\text { Boden et } \\
\text { al }\end{array}$ & 1983 & $\begin{array}{l}27 \\
\text { year } \\
\text { old } \\
\text { male }\end{array}$ & $\begin{array}{l}\text { Bioprosthetic AV, on } \\
\text { prednisone for } \\
\text { nephrotic syndrome }\end{array}$ & $\begin{array}{l}\text { Aortic } \\
\text { valve }\end{array}$ & $\begin{array}{l}\text { Fungemia } \\
\text { Meningitis }\end{array}$ & $\begin{array}{l}\text { Ampho } B+ \\
\text { flucytosine } x \\
42 \text { days }\end{array}$ & $\begin{array}{l}\text { Valvular } \\
\text { replacement }\end{array}$ & Alive \\
\hline $\begin{array}{l}\text { Velasco et } \\
\text { al }\end{array}$ & 1990 & $\begin{array}{l}26 \\
\text { year } \\
\text { old } \\
\text { male }\end{array}$ & HIV & $\begin{array}{l}\text { Aortic } \\
\text { valve }\end{array}$ & $\begin{array}{l}\text { Cerebral } \\
\text { abscess }\end{array}$ & & None & Died \\
\hline $\begin{array}{l}\text { Banerjee } \\
\text { et al }\end{array}$ & 1996 & $\begin{array}{l}48 \\
\text { year } \\
\text { old } \\
\text { male }\end{array}$ & $\begin{array}{l}\text { MV replacement, } \\
\text { rheumatic heart } \\
\text { disease }\end{array}$ & $\begin{array}{l}\text { Mitral } \\
\text { valve }\end{array}$ & $\begin{array}{l}\text { Embolus to } \\
\text { brachial } \\
\text { artery, } \\
\text { brain }\end{array}$ & Ampho B & None & Died \\
\hline Blanc et al & 1996 & $\begin{array}{l}12 \\
\text { year } \\
\text { old } \\
\text { male }\end{array}$ & $\begin{array}{l}\text { Rheumatic heart } \\
\text { disease } s / \mathrm{p} \text { mitral } \\
\text { annuloplasty and } \\
\text { tricuspid plasty, Class } \\
\text { IV CHF } \\
\text { Malnutrition }\end{array}$ & $\begin{array}{l}\text { Mitral } \\
\text { Valve }\end{array}$ & $\begin{array}{l}\text { Cerebral } \\
\text { abscess } \\
\text { Fungemia }\end{array}$ & $\begin{array}{l}\text { Ampho B + } \\
\text { fluconazole } \\
\text { maintenance }\end{array}$ & $\begin{array}{l}\text { Valvular } \\
\text { replacement }\end{array}$ & Alive \\
\hline Alhaji et al & 2011 & $\begin{array}{l}41 \\
\text { year } \\
\text { old } \\
\text { male }\end{array}$ & $\begin{array}{l}\text { Prosthetic AV, } \\
\text { biscupid AV }\end{array}$ & $\begin{array}{l}\text { Aortic } \\
\text { valve }\end{array}$ & Fungemia & Ampho B & None & Alive \\
\hline $\begin{array}{l}\text { Kurian et } \\
\text { al (present } \\
\text { report) }\end{array}$ & 2020 & $\begin{array}{l}60 \\
\text { year } \\
\text { old } \\
\text { female }\end{array}$ & Lung cancer & $\begin{array}{l}\text { Aortic } \\
\text { valve }\end{array}$ & $\begin{array}{l}\text { Fungemia } \\
\text { Meningitis } \\
\text { Probable } \\
\text { lung }\end{array}$ & Ampho B & None & Died \\
\hline
\end{tabular}

AV: Aortic Valve; HIV: Human Immunodeficiency virus; MV: Mitral Valve; s/p: status post; CHF: Congestive Heart Failure; UTI: Urinary Tract Infection; ampho B: amphotericin B. 
Another unique clinical feature in our patient is the absence of prosthetic valve or significant valvular disease history. Six of the seven prior cases presented with septic demobilization of the fungal endocarditis including two cases of meningitis, three cases of cerebral abscess, one case of brachial artery embolus, and one case of urinary tract involvement. Our patient presented with fungemia and meningitis likely secondary to septic demobilization of the fungal nidus on the valve. Given the previously seen cases that occurred between the 1950s and 2010s, there is understandably significant variability in the approach of management. Notably, four of the seven patients survived and were clear of disease upon 6-24 months follow up. These results suggest that although the clinical presentation of Cryptococcal endocarditis is quite rare, it is a treatable condition. Finally, of the patients who survived, two had valve replacement with medical management while the rest had medical management alone.

This case compels us to ponder why our patient presented with Cryptococcal endocarditis. The subset of patients with significant disease burden from metastatic lung cancer that benefit from targeted therapies such as erlotinib are now experiencing improved survival but may be at risk for comorbidities that may have been rarely seen in the past. These comorbidities may include rare infectious processes given the alterations in the immune system that result from malignant disease or the treatments.

Multiple studies of EGFR-TKIs reveal fewer treatment-related severe side effects and deaths when compared to standard chemotherapy [3-8]. Cytopenias, including neutropenia were among the most common adverse reactions seen in cytotoxic chemotherapy but not seen in patients treated with EGFR-TKIs. Ongoing work in the field suggests that some of these targeted agents may have effects on the immune system in ways clinicians were not previously aware, including alteration of the immune landscape, direct modification of tumor cells, and improved vascular perfusion to promote anti-tumor activity [23]. Although these developments suggest targeted agents may have broader impact on a patient's immune system than previously known, further studies are needed to investigate this theory.

\section{Conclusion}

This report represents the first known case of Cryptococcal endocarditis in a patient with active malignancy receiving targeted therapy. With the advent of several new targeted therapeutic agents and limited long-term data, further investigation is needed regarding possible increased risk of infectious diseases. The astute clinician should avoid anchoring bias and consider a broad differential diagnosis when considering patients with active malignancy receiving targeted therapy.

\section{Disclosure}

FA received grant from Hektoen Institute and honorarium from BioFire. Rest of the authors have nothing to declare.

\section{Funding}

None.

\section{Author Contributions}

TK, JP and FA wrote the manuscript. TK, JP and FA were involved in the patient's care. TK, JP, FA and CW read, revised and approved the manuscript.

\section{REFERENCES}

1. Dowell J, Minna JD, Kirkpatrick P (2005) Erlotinib hydrochloride. Nat Rev Drug Discov 4: 13-14. [Crossref]

2. Kantarjian MD (2011) Anderson Manual of Medical Oncology (2nd ed.). McGraw-Hill.

3. Rosell R, Carcereny E, Gervais R, Vergnenegre A, Massuti B et al. (2012) Erlotinib versus standard chemotherapy as first-line treatment for European patients with advanced EGFR mutation-positive nonsmall-cell lung cancer (EURTAC): a multicentre, open-label, randomised phase 3 trial. Lancet Oncol 13: 239-246. [Crossref]

4. Zhou C, Wu Y, Chen G, Feng J, Liu X et al. (2011) Erlotinib versus chemotherapy as first-line treatment for patients with advanced EGFR mutation-positive non-small-cell lung cancer (OPTIMAL, CTONG0802): a multicentre, open-label, randomised, phase 3 study. Lancet Oncol 12: 735-742. [Crossref]

5. Mok TS, Wu Y, Thongprasert S, Yang C, Chu D et al. (2009) Gefitinib or carboplatin-paclitaxel in pulmonary adenocarcinoma. $N$ Engl J Med 361: 947-957. [Crossref]

6. Mitsudomi T, Morita S, Yatabe Y, Negoro S, Okamoto I et al. (2010) Gefitinib versus cisplatin plus docetaxel in patients with non-small-cell lung cancer harbouring mutations of the epidermal growth factor receptor (WJTOG3405): an open label, randomised phase 3 trial. Lancet Oncol 11: 121-128. [Crossref]

7. Maemondo M, Inoue $A$, Kobayashi K, Sugawara S, Oizumi S et al. (2010) Gefitinib or chemotherapy for non-small-cell lung cancer with mutated EGFR. N Engl J Med 362: 2380-2388. [Crossref]

8. Sequist LV, Yang JC, Yamamoto N, O'Byrne K, Hirsh V et al. (2013) Phase III study of afatinib or cisplatin plus pemetrexed in patients with metastatic lung adenocarcinoma with EGFR mutations. J Clin Oncol 31: 3327-3334. [Crossref]

9. Ettinger DS, Wood DE, Aisner DL, Akerley W, Bauman J et al. (2017) Non-Small Cell Lung Cancer, Version 5.2017, NCCN Clinical Practice Guidelines in Oncology. J Natl Compr Canc Netw 15: 504-535. [Crossref]

10. Cohen MH, Johnson JR, Chen Y, Sridhara R, Pazdur R (2005) FDA drug approval summary: erlotinib (Tarceva) tablets. Oncologist 10: 461-466. [Crossref]

11. Burotto M, Manasanch EE, Wilkerson J, Fojo T (2015) Gefitinib and erlotinib in metastatic non-small cell lung cancer: a meta-analysis of toxicity and efficacy of randomized clinical trials. Oncologist 20: 400410. [Crossref]

12. Snygg Martin U, Gustafsson L, Rosengren L, Alsiö A, Ackerholm P et al. (2008) Cerebrovascular complications in patients with left-sided infective endocarditis are common: a prospective study using magnetic resonance imaging and neurochemical brain damage markers. Clin Infect Dis 47: 23-30. [Crossref]

13. Katsouli A, Massad MG (2013) Current issues in the diagnosis and management of blood culture-negative infective and non-infective endocarditis. Ann Thorac Surg 95: 1467-1474. [Crossref] 
14. Baddour LM, Wilson WR, Bayer AS, Fowler VG Jr, Tleyjeh IM et al. (2015) Infective Endocarditis in Adults: Diagnosis, Antimicrobial Therapy, and Management of Complications: A Scientific Statement for Healthcare Professionals From the American Heart Association. Circulation 132: 1435-1486. [Crossref]

15. Lombardo TA, Rabson AS, Dodge HT (1957) Mycotic endocarditis; report of a case due to Cryptococcus neoformans. Am J Med 22: 664670. [Crossref]

16. Colmers RA, Irniger W, Steinberg DH (1967) Cryptococcus neoformans endocarditis cured by amphotericin B. JAMA 199: 762764. [Crossref]

17. Boden WE, Fisher A, Medeiros A, Benham I, McEnany MT (1983) Bioprosthetic endocarditis due to Cryptococcus neoformans. $J$ Cardiovasc Surg (Torino) 24: 164-166. [Crossref]

18. Velasco L, Barriales V, Moreno A, Sánchez Gómez Navarro J, Giribet A (1990) Endocarditis caused by Cryptococcus on a native valve, in a patient with AIDS. Rev Clin Esp 186: 99-100. [Crossref]
19. Banerjee U, Gupta K, Venugopal P (1997) A case of prosthetic valve endocarditis caused by Cryptococcus neoformans var. neoformans. $J$ Med Vet Mycol 35: 139-141. [Crossref]

20. Blanc V, Lavarde V, Thanh NT, Tri HHQ, Guillemain R et al. (1996) Postoperative Cryptococcus neoformans endocarditis. Clin Microbiol Infect 2: 66-69. [Crossref]

21. Alhaji M, Sadikot RT (2011) Cryptococcal endocarditis. South Med J 104: 363-364. [Crossref]

22. Perfect JR, Dismukes WE, Dromer F, Goldman DL, Graybill JR et al. (2010) Clinical practice guidelines for the management of cryptococcal disease: 2010 update by the Infectious Diseases Society of America. Clin Infect Dis 50: 291-322. [Crossref]

23. Kwilas AR, Donahue RN, Tsang KY, Hodge JW (2015) Immune consequences of tyrosine kinase inhibitors that synergize with cancer immunotherapy. Cancer Cell Microenviron 2: e677. [Crossref] 